\title{
Laboratuvar tasarımı bir HBV DNA kantitasyon protokolü rutin kullanıma uygun olabilir mi? - Ege Üniversitesi Klinik Viroloji Laboratuvarı deneyimi
}

Would a laboratory designed HBV DNA quantification protocol be appropriate for routine use? - Ege University Clinical Virology Laboratory's experience

\author{
Ajda Turhan ${ }^{1} \quad$ İmre Altuğlu $^{2} \quad$ Selda Erensoy ${ }^{2} \quad$ Rüçhan Sertöz ${ }^{2}$ \\ ${ }^{1}$ Ege Üniversitesi Tıp Fakültesi, Kan Merkezi, İzmir, Türkiye \\ ${ }^{2}$ Ege Üniversitesi Tıp Fakültesi, Tıbbi Mikrobiyoloji Anabilim Dalı, İzmir, Türkiye
}

\section{Öz}

Amaç: Hepatosellüler karsinoma ve fatal karaciğer hasarına yol açması nedeniyle ülkemizde de önemli bir halk sağlığı sorunu olan kronik Hepatit B enfeksiyonunun izleminde Hepatit B virüs (HBV) DNA kantitasyonu önemli bir göstergedir. Klinik viroloji laboratuvarlarında HBV DNA kantitasyonu için kullanılan birçok farklı yöntem ve sistemler mevcuttur. Bu çalışmanın amacı laboratuvar tasarımı gerçek zamanı bir PCR protokolün Ege Üniversitesi Tıp Fakültesi Hastanesi Tıbbi Mikrobiyoloji Anabilim Dalı Viroloji/Moleküler Biyoloji laboratuvarında ABI Prism 7500 (PE Biosystems) için uygunluğunun değerlendirilmesi ve rutin kullanılan HBV DNA test COBAS AmpliPrep-COBAS TaqMan 48 (CAP-CTM; Roche, Branchburg, NJ) HBV DNA testi ile karşılaştııılmasıdır.

Gereç ve Yöntem: HBV DNA saptanmasına yönelik geliştirimiş, laboratuvar tasarımı, Taqman teknolojisine dayanan, bir gerçek zamanlı test Ege Üniversitesi Tıp Fakültesi Hastanesi Tıbbi Mikrobiyoloji Anabilim Dalı Viroloji/Moleküler Biyoloji laboratuvarında denendi. Rutin HBV DNA kantitasyonu amacıyla gönderilen 332 örnek çalışmaya alındı ve kullanılmakta olan HBV DNA test COBAS AmpliPrep-COBAS TaqMan 48 HBV DNA testi ile karşılaştırıldı.

Bulgular: 332 örneğin 176'sının sonuçları protokolün dinamik aralığı içinde idi. Dinamik aralık içinde olan 176 örneğin kantitatif sonuçları uyumlu idi. 106 örnek her iki sistem ile negatif bulundu.

Sonuç: Laboratuvar tasarımlı HBV DNA kantitatif protokolünün klinik viroloji laboratuvarında uygulanabilir, rutin tanı ve klinik pratikte HBV ile infekte hastaların izlenmesi için uygun, ucuz, geniş dinamik aralık sağlayan bir yöntem olduğu sonucuna varıldı.

Anahtar Sözcükler: Kronik HBV enfeksiyonu, HBV DNA kantitasyonu, gerçek zamanlı PCR.

\section{Abstract}

Aim: Hepatitis B virus (HBV) DNA quantification is an important indicator during the follow-up of chronic hepatitis $B$ infection, which has a major public health impact in Turkey due to its hepatocellular carcinoma and fatal liver damage end-points. There are many different methods and systems used in clinical virology laboratories for HBV DNA quantification. The aim of this study was to test whether a laboratory designed real time assay protocole would be compatible with ABI Prism 7500 (PE Biosystems) in Ege University Medical School's Virology/Molecular Biology laboratory and to compare it with the routinely used COBAS AmpliPrep-COBAS TaqMan 48 (CAP-CTM, Roche, Branchburg, NJ) HBV DNA test.

Materials and Methods: A real time test based on Taqman technology to detect HBV DNA was designed in the Virology/Molecular Biology Laboratory of Ege University Medical School's Medical Microbiology Department and it was evaluated. 332 samples sent to the laboratory for HBV DNA quantification were included in the study and were compared with the COBAS AmpliPrep-COBAS TaqMan 48 HBV DNA test routinely used in the laboratory.

Results: HBV DNA results of 176 out of 332 samples were in the dynamic range of the protocol. The quantitative results of 176 samples in dynamic range were concordant. The results of 106 samples were negative according to both systems.

\footnotetext{
Yazışma Adresi: Ajda TURHAN

Ege Üniversitesi Tıp Fakültesi, Kan Merkezi, İzmir, Türkiye

Makalenin Geliş Tarihi: 17.07.2014 Kabul Tarihi: 14.08.2014
} 
Conclusion: The laboratory designed HBV DNA quantification protocole can be used in the clinical virology laboratory for the routine diagnosis and follow-up of HBV infected patients and it is a suitable and cheap method enabling a wide dynamic range.

Keywords: Chronic hepatitis B infection, HBV DNA quantification, real time PCR.

\section{Giriş}

Kronik HBV enfeksiyonu, hepatosellüler karsinomanın majör risk faktörü olması ve fatal karaciğer hasarı yaratması nedeniyle önemli bir halk sağlığı sorunudur (1). Dünya genelinde tahminen 350 - 400 milyon kişi Hepatit B virüsü ile kronik olarak enfektedir (2). Global olarak bu enfeksiyonlar en yaygın ölüm nedenleri arasında onuncu sırada yer almakta (3), yılda yarım milyon insan kronik Hepatit $B$ enfeksiyonu nedeniyle ölmektedir (4).

Hepatit B virüsü (HBV) viremisi kronik HBV enfeksiyonunun progresyonunda önemli bir risk faktörüdür, dolayısıyla kanda HBV DNA kantitasyonu kronik enfeksiyonun izleminde ve hasta yönetiminde önemli bir gösterge olmaktadır (5). HBV DNA saptanması ve kantitasyonu;

1. Karaciğer hastalığının prognozunu belirlemede (siroza ya da hepatosellüler karsinoma progresyon riski),

2. Antiviral tedaviye gereksinim duyan hastaların belirlenmesinde,

3. Virolojik yanıtın ve antiviral tedaviye direncin izlenmesinde kullanılmaktadır (6).

Günümüzde DNA saptanması ve kantitasyonuna yönelik birçok yöntem bulunmaktadır. Hibrid yakalama ya da PCR veya dallı DNA teknolojisi yoluyla sinyal amplifikasyonu temeline dayanan bu yöntemler zayıf analitik duyarlılık ve HBV DNA kantitasyon aralığının dar olması gibi dezavantajlara sahiptirler. Son yıllarda gerçek zamanlı PCR temeline dayalı yöntemler geliştirilmiştir. Analitik duyarlılıkları (alt saptama sınırı 10-20 $\mathrm{IU} / \mathrm{mL}$ ), spesifikliği, rutine uyarlanabilirliği ve geniş dinamik aralığı nedeniyle bu testler hem saptama hem de DNA kantitasyonunda önerilen testlerdir (7-10). Dünya Sağlık Örgütü, HBV DNA konsantrasyonu ifadesinin normalizasyonu için uluslararası bir standart belirlemiştir (11). Karşılaştırılabilirliği sağlamak adına serum HBV DNA düzeyleri IU/mL olarak ifade edilmeli ve antiviral etkinliği değerlendirmek adına hasta yönetiminde aynı test kullanılmalıdır (12).

Ege Üniversitesi Tıp Fakültesi Hastanesi Tıbbi Mikrobiyoloji Anabilim Dalı Viroloji/Moleküler Biyoloji laboratuvarında da HBV-DNA testi en çok çalışılan nükleik asit testidir. 1993'den beri HBV-DNA düzeyini belirlemek için satın alma sistemlerine bağlı olarak rutinde değişik ticari yöntemler kullanılmıştır.

Laboratuvar tasarımlı bir testin ise HBV enfeksiyonu yönetimi gibi iddialı bir alanda kullanılabilmesi için yöntemin olabildiğince güvenilir olması gerekir. Bu amaçla Erasmus MC Moleküler Biyoloji bölümünde 2000 yılından beri rutin olarak çalışılan bir HBV DNA protokolü seçilmiştir. Pas ve ark. (13), tasarladıkları bu gerçek zamanlı PCR yöntemiyle kantitatif HBV-DNA testini ABI 7700 cihazında geçerlilik ve performansını değerlendirerek yayınlamışlardır. Bu protokol ile kantitatif HBV DNA testini uygulayan çeşitli merkezler bulunmaktadır. Ancak rutin uygulamaya geçmeden önce laboratuvar koşullarında yöntemin geçerlilik çalışmalarının yapılması şarttır.

Bu çalışmada, aynı protokolün laboratuvarımızda aynı koşullarda kronik B Hepatitli hastaların tanı, takip ve izleminde $\mathrm{ABI}$ Prism 7500 (PE Biosystems) için uygunluğunun değerlendirilmesi ve rutin kullanılan HBV DNA test COBAS AmpliPrep-COBAS TaqMan 48 (CAPCTM; Roche, Branchburg, NJ) HBV DNA testi ile karşılaştırılması amaçlanmış ve standardize edilerek rutine uyarlanması planlanmıştır.

\section{Gereç ve Yöntem}

Klinik Mikrobiyoloji laboratuvarına rutin HBV DNA kantitasyonu amacıyla gönderilen 332 örnek çalışmaya alındı ve nükleik asit izolasyonu EZ1 Virus Mini Kit v2.0 kiti ile BioRobot EZ1 Advanced istasyonunda (Qiagen, Germany) yapıldı. Daha önce Pas ve arkadaşları tarafından ABI Prism 7700 cihazı için tasarlanan gerçek zamanlı HBV DNA PCR protokolu (13), protokolün tanımlandığı laboratuvardan tüm ayıraç ve gereçleri, primer ve probları sağlanacak şekilde uygulandı.

Primerler ve prob HBV genomunun pre-S bölgesini hedef almaktaydı. Isı döngü programı tanımlanan şekilde uygulandı (2 dakika $50^{\circ} \mathrm{C}, 10$ dakika $95^{\circ} \mathrm{C}$ 'nin ardından 50 döngü - 15 saniye $95^{\circ} \mathrm{C}$ ve 60 saniye $60^{\circ} \mathrm{C}$ ).

Her örnek protokolde tanımlandığı üzere çift çalışıldı ve iki sonucun ortalaması değerlendirmeye alındı. Testin dinamik aralığı $373-10^{10} \mathrm{kopya} / \mathrm{ml}$, analitik duyarlılığı 373 kopya/ml idi. Örnekler laboratuvarımızda HBV DNA kantitasyonu için rutin olarak COBAS AmpliPrep-COBAS TaqMan 48 (CAP-CTM; Roche, Branchburg, NJ) ile çalışıldı (54-1.1 × $\left.10^{8} \mathrm{IU} / \mathrm{mL}\right)$.

Protokolün analitik duyarlılık ve dinamik aralık çalışmaları VQC (Viral Kalite Kontrol panelleri-Hollanda) referans serumları ile çalışılarak tanımlandı. Açılan her yeni reaktifin kontrolü HBV DNA VQC paneli ile çift çalışılarak yapıldı.

\section{Bulgular}

332 örneğin 176'sının sonuçları protokolün dinamik aralığı içinde idi. Dinamik aralık içinde olan 176 örneğin kantitatif sonuçları uyumlu idi $\left(r^{2}: 0.88\right)$ (Şekil-1). 106 
örnek her iki sistem ile negatif bulundu. Geri kalan 50 örnek içinde; 14'ü her iki yöntemin üst saptama sınırının üzerinde olduğu için kantitatif karşılaştırma yapılamadı. 30 örnek ABI Prism 7500 (PE Biosystems) ile düşük pozitif ancak COBAS AmpliPrep-COBAS TaqMan 48 (Roche, Branchburg, NJ CAP-CTM) ile negatif idi. Altı örnek ABI Prism 7500 (PE Biosystems) ile negatif COBAS AmpliPrep-COBAS TaqMan 48 (Roche, Branchburg, NJ CAP-CTM) ile düşük pozitif olarak saptandı. 176 örneğin dışındaki örneklerin sonuçları Tablo-1'de görülmektedir.

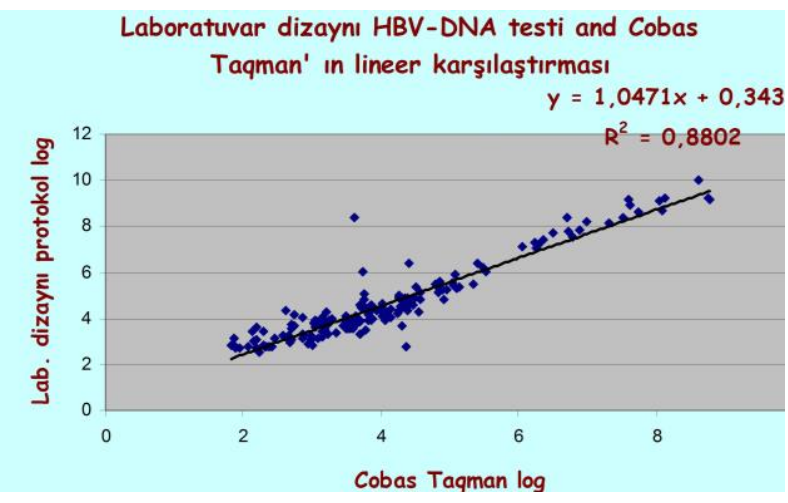

Şekil-1. 176 örnekte laboratuvar dizaynı protokol ve Cobas Taqman'ın lineer karşılaştırması.

Tablo-1. 176 Örneğin Dışındaki Örneklerin Laboratuvar Dizaynı Protokol ve Cobas Taqman Sonuçlarının Karşılaştırılması.

\begin{tabular}{l|l|c|c}
\hline $\begin{array}{l}\text { LAB. } \\
\text { PROTOKOL }\end{array}$ & $\begin{array}{c}\text { COBAS } \\
\text { TAQMAN }\end{array}$ & $\begin{array}{c}\text { 176 ÖRNEGIN } \\
\text { DIŞINDAKI } \\
\text { 156 ÖRNEK } \\
\text { IÇiN SAYI VE } \\
\text { ORAN (\%) }\end{array}$ & $\begin{array}{c}\text { TOPLAM 332 } \\
\text { HASTA } \\
\text { IÇERISINDEN } \\
\text { ORAN (\%) }\end{array}$ \\
\hline Negatif & Negatif & $106(68)$ & 31.9 \\
\hline $\begin{array}{l}\text { Üst } \\
\text { Saptama } \\
\text { Sınırı }\end{array}$ & $\begin{array}{l}\text { Üst } \\
\text { Saptama }\end{array}$ & $14(8,9)$ & 4.2 \\
\hline Sozinırı & Negatif & $30(19.3)$ & 9.0 \\
\hline Negatif & Pozitif & $6(3.8)$ & 1.8 \\
\hline & & $156(100)$ & 46.9 \\
\hline
\end{tabular}

\section{Tartışma}

Halen HBV enfeksiyonunun tanı ve rutin izleminde dinamik aralıkları, birimleri birbirinden farklı pek çok yöntem kullanılmaktadır. Kronik B hepatitli hastaların DNA ölçümlerinin değerlendirilmesinde gerekli düzeyleri kapsayabilmek için farklı dinamik aralığa sahip testlerin veya ek sulandırım basamaklarının kullanılması gerekmektedir $(14,15,16)$. Yöntem farklılığı nedeniyle sonuçların birbirine çevrilememesi hasta izleminde sıkıntı yaratmaktadır. Ülkemizde hastaların aynı yöntem ile izlenememesi bir diğer sorundur. Gerçek zamanlı PCR teknolojisinde daha geniş dinamik aralık ve yüksek duyarlılık sağlanabilir. Bu yöntem, ml'de $373-10^{10}$ kopya aralığında HBV DNA'yı dilusyon ya da konsantrasyon gereksinimi olmadan saptayabilmektedir.

Özellikle antiviral tedavi alan hastalarda örneğin HBV DNA düzeyinin hangi aralıklarda beklendiği bilinmediğin- den tekrarlayan testlere gereksinim duyulmaktadır (17). Tarif edilen gerçek zamanlı PCR yöntemi ile bu problem ortadan kalkmıştır. Ayrıca bu teknoloji HBV DNA kantitasyonunu, spesifik sekansları saptamak için gerekli olan PCR amplikon işleme adımlarına ihtiyaç olmadan kolayca gerçekleştirebildiğinden kullanılmakta olan yöntemlerin yerini alabilir (18). Ancak rutin tanı laboratuvarlarında kullanılabilmesi için kantitatif viral testlerin güvenilirliğinin kanıtlanması, dolayısıyla laboratuvarın testleri yeterince çalışma ile kontrol edip değerlendirmesi gerekir.

Çalışmamızda 176 örnek (\%53) her iki testin dinamik aralığı içinde olup sonuçları birbirleri ile uyumlu olarak saptanmıştır (Şekil-1). Diğer yandan 176 örneğin dışında kalan 156 örnekten 106 tanesi $(\% 31,9)$ her iki yöntemle de negatif olarak bulunmuştur. Yine 14 örnek $(\% 4,2)$ her iki sistemle de üst saptama sınırının üzerinde olarak saptanmış fakat bu nedenle kantitatif karşılaştırma yapılamamıştır. Karşılaştırmalı sonuçların uyumsuz olarak gözlendiği 36 örnekten 30 tanesi (\%9) ABI Prism 7500 (PE Biosystems) ile düşük pozitif, diğer negatif olarak saptanmış olup ABI Prism 7500 (PE Biosystems) lehine değerlendirilerek duyarlılığının daha yüksek olduğunu düşündürmüştür. 176 örneğin dışındaki 156 örneğe ait veriler Tablo-1'de izlenmektedir.

$\mathrm{Bu}$ yöntem rutin tanı ve klinik pratikte HBV ile infekte hastaların izlenmesi için uygun, ucuz, geniş dinamik aralık sağlayan bir yöntem olmakla birlikte, düşük pozitifliklerdeki farklı sonuçlar düşük değerlerde rastlantısal örneklemeye bağlı farklı sonuçlar elde edilebilir olmasından (Poisson dağılımı) kaynaklanmaktadır. In house PCR yöntemlerinde, standardizasyon sorunları, yalancı pozitiflik ya da kontaminasyon gibi rutin klinik diagnostik kullanımda onları uygunsuz kılan problemler oluşabildiği bilinmektedir (19). Buna rağmen, ticari ya da in house yöntemlerde hala en kritik adım örneğin hazırlanmasıdır. İyi laboratuvar uygulamaları prensiplerine dikkat edilerek gerçekleştirildiği takdirde kontaminasyon önlenebilmektedir. Çalışmada, kontaminasyona bağlı yalancı pozitiflik olasılığı PCR çalışma kurallarına dikkat edildiği ve sık kontaminasyon kontrolü yapıldığından dışlanmıştır. Ayrıca her örneğin çift çalışıması, yalancı pozitifliğin kolaylıkla gözlenebilmesini sağlamıştır.

\section{Sonuç}

Laboratuvar tasarımlı HBV DNA kantitatif protokolü gibi ucuz, standart, rutine kolay uyarlanabilen yöntemlerin varlığı hasta yönetiminde standardizasyonu ve ekonomik avantajı sağlayabilecektir. Tasarlanan bu yöntemin kantitasyon aralığının geniş olması ile hastaların tedavi endikasyonundan itibaren aynı yöntem ile izlenebilmesine olanak vermektedir. Sonuç olarak, bu yöntem klinik viroloji laboratuvarında HBV DNA ölçümü için uygulanabilir bir yöntemdir. Ancak düşük pozitifliklerdeki farklı sonuçlar yine hasta takibinde tek yöntemin kullanılmasının uygun olduğunu göstermektedir. 


\section{Kaynaklar}

1. Lok AS, McMahon BJ. Chronic Hepatitis B. Hepatology 2001;34(6):1225-41.

2. Lee WM. Hepatitis B virus infection. N Engl J Med 1997;337(24):1733-45.

3. Lavanchy D. Hepatitis B virus epidemiology, disease burden, treatment, and current and emerging prevention and control measures. J Viral Hepat 2004;11(2):97-107.

4. Dienstag JL. Hepatitis B virus infection. N Engl J Med 2008;359(14):1486-500.

5. Caliendo AM, Valsamakis A, Bremer JW, et al. Multilaboratory evaluation of real-time PCR tests for hepatitis B virus DNA quantification. J Clin Microbiol 2011;49(8):2854-8.

6. Pawlotsky JM. Hepatitis B virus (HBV) DNA assays (methods and practical use) and viral kinetics. J Hepatol 2003;39 Suppl 1:S31-5.

7. Pawlotsky JM, Dusheiko G, Hatzakis A, et al. Virologic monitoring of hepatitis B virus therapy in clinical trials and practice: Recommendations for a standardized approach. Gastroenterology 2008;134(2):405-15.

8. Chevaliez S, Bouvier-Alias M, Laperche S, Pawlotsky JM. Performance of the Cobas AmpliPrep/Cobas TaqMan real-time PCR assay for hepatitis B virus DNA quantification. J Clin Microbiol 2008;46(5):1716-23.

9. Thibault V, Pichoud C, Mullen C, et al. Characterization of a new sensitive PCR assay for quantification of viral DNA isolated from patients with hepatitis B virus infections. J Clin Microbiol 2007;45(12):3948-53.

10. Stelzl E, Muller Z, Marth E, Kessler HH. Rapid quantification of hepatitis B virus DNA by automated sample preparation and real-time PCR. J Clin Microbiol 2004;42(6):2445-9.

11. Saldanha J, Gerlich W, Lelie N, Dawson P, Heermann K, Heath A; WHO Collaborative Study Group. An international collaborative study to establish a World Health Organization international standard for hepatitis B virus DNA nucleic acid amplification techniques. Vox Sang 2001;80(1):63-71.

12. Chevaliez S, Bouvier-Alias M, Laperche S, Hézode C, Pawlotsky JM. Performance of version 2.0 of the Cobas AmpliPrep/Cobas TaqMan real-time PCR assay for hepatitis B virus DNA quantification. J Clin Microbiol 2010;48(10):3641-7.

13. Pas SD, Fries E, De Man RA, Osterhaus AD, Niesters HG. Development of a quantitative real-time detection assay for hepatitis B virus DNA and comparison with two commercial assays. J Clin Microbiol 2000;38(8):2897-901.

14. Franchis R, Hadenque A, Lau G, et al. EASL International Consensus Conference on Hepatitis B. 13-14 September, 2002 Geneva, Switzerland. Consensus Statement (long version). J Hepatol 2003, 39(Suppl 1): 3-25.

15. Kessler HH, Stelzl E, Daghofer E, et al. Semiautomated quantification of Hepatitis B virus DNA in a routine diagnostic laboratory. Clin Diagn Lab 2000;7(5):853-5.

16. Sertoz RY, Erensoy S, Pas S, Niesters HG. Hepatit B virus DNA kantitasyonunda ABI Prism 7000 ile 7700 sekans saptama cihazlarının sonuçlarının birbiri ile uygunluğunun araştırılması. Mikrobiyol Bul 2005;39(2):175-81.

17. Noborg U, Gusdal A, Pisa EK, Hedrum A, Lindh M.J. Automated quantitative analysis of hepatitis B virus DNA by using the Cobas Amplicor HBV monitor test. Clin Microbiol 1999;37(9):2793-7.

18. Honkoop P, de Man RA, Niesters HG. Quantitative assessment of hepatitis B virus DNA during a 24-week course of lamivudine therapy. Ann Intern Med 1998;128(8):697.

19. Persing DH. Polymerase chain reaction: Trenches to benches. J Clin Microbiol. 1991;29(7):1281-5. 